\section{House panel}

\section{examines}

\section{overseas ties}

\section{Washington}

University involvement with the commercial exploitation of genetic engineering is well on the way to becoming an issue between the United States government and the universities. Last week, at a meeting of Congressman Albert Gore's oversight subcommittee of the House Committee on Science and Technology, representatives of the Massachusetts General Hospital were hauled over the coals because of the hospital's agreement with Hoechst AG under the terms of which the German chemical company will provide $\$ 50$ million over the next ten years to run a molecular biology laboratory at the hospital, and will have first refusal of any patent licences that may result.

At the hearings, Dr Ronald Lamont Havers, Director of research at the hospital, demurred when asked to provide the subcommittee with a copy of the agreement it has signed with Hoechst. The subcommittee's chairman left the hospital and everybody else within earshot in no doubt of his belief that universities sustained for the past twenty years by federal grants should be careful not to give overseas enterprises favoured access to their expertise. There is now some talk that the subcommittee will subpoena the agreement between the Massachusetts General Hospital and Hoechst if the document does not turn up in the mail before too long.

The grant from Hoechst will be used to found a department of molecular biology at the hospital. Dr Howard M. Goodman of the University of California, San Francisco, will be the director of the enterprise, the staff of which is expected to grow to about 50 by 1983 and thereafter to 100. The hospital insists that the programme of research will be determined by the hospital alone, while the work of the department will be reviewed by a committee of six scientists independent of Hoechst. The operation of the agreement between the company and the hospital will be kept under review by a joint committee of three senior managers of the company and three trustees from the hospital.

The declared objective of the new department is to apply the techniques of molecular biology to the treatment of disease. The hospital says that all appointments in the new department will be made according to established academic procedures, that individual scientists will be free to publish how and when they choose provided that the hospital authorities are informed in advance, and that there will be no restrictions on collaboration with scientsts elsewhere.

According to the hospital, patentable discoveries will be patented by the hospital, and the benefits shared between the hospital and the inventor on the basis of existing rules. Hoechst will have a right to a licence to any patent springing from research which it has sponsored, while the royalty rate negotiated "will reflect the financial contribution of the company".

Two potentially contentious aspects of the agreement are that the company will be free to decide whether or not particular research projects should be funded out of the $\$ 50$ million set aside, and that members of the new department working on Hoechst-sponsored projects will not be free to consult with other companies. The agreement is automatically renewable if not terminated after ten years.

It has also been agreed that there will be a public seminar once a year to which some Hoechst scientists will be invited, and that the company will have a right to send up to four of its people to the hospital for training at any time.

Congressman Gore is unlikely to let these issues fade away. After last week's hearings, he said that "the questions that

\title{
NIH plan new overhead calculation
}

Academic research administrators will soon have to learn new algorithms for calculating how much overhead to charge against successful applications for research grants and contracts with the National Institutes of Health (NIH). So much is clear from the meeting last week (8-9 June) of the Institute's Advisory Committee, at which the task force led by Professor Samuel O. Thier of Yale University that has been brooding on the question of "institutional support" (bureaucratic jargon for overhead) promised to produce at the next meeting in October several proposals for reorganizing the present system.

Objections to the present system are several. Research grant proposals approved by study sections of NIH (the "peer review" committees) are made more costly by an amount negotiated between NIH and the recipient institutions intended to cover the cost of supporting the research concerned. On the average, NIH overheads cost 30 per cent of total expenditure on research grants and contracts. There are wide geographical variations, with the universities in the north-west of the United States successfully claiming larger percentages for institutional support than universities elsewhere.

The stimulus for the present review has come from federal agencies and universities, both equally appalled at the difficulties of carrying out the detailed accounting for research grant expenditure now required of them. But $\mathrm{NIH}$ also have an interest in heading off trouble about institutional support from the Reagan Administration, which has already shown its hand by removing from the NIH budget institutional support accompanying awards of postdoctoral fellowships.

The Thier task force plans to spend the summer assessing the merits of alternative mechanisms for providing institutional support. The favoured alter- native to the present system appears to be the "fixed obligation" formula, under which research grants and contracts would be awarded on what is essentially a fixed-price basis, and on which federal investigation would be limited to a simple verification that direct and indirect costs have been properly incurred.

At the next meeting of the Advisory Committee in October, the task force will suggest that experiments should be carried out with several of the alternative methods of financial research projects. It is, however, unlikely that all the loose ends can be tied up by October - it is not, for example, at this stage clear whether the overhead element in fixed obligation grants should be assessed by a peer review committee and, if so, whether should be the appropriate study section.

Last week's meeting of the NIH Advisory Committee also wrestled a little inconclusively with the issue of patent rights in biological innovations.

One curious development to come to light was that many scientists are cheerfully ignoring the provisions of the Patents and Trademark (Amendments) Act of 1979. This legislation gives universities at which research grants are held the right to patent and exploit new developments, reserving to the federal government a non-exclusive right to a licence. Under the amended law, those holding grants from $\mathrm{NIH}$ are required to report all patentable developments.

These provisions have already been found unworkable in the development of monoclonal antibodies, each one of which may be potentially patentable. Given that a productive laboratory may expect to develop several hundreds of monoclonal antibodies a year, and that the cost of patent protection is a minimum of $\$ 2,000$, it seems to have been tacitly assumed that only those monoclonal antibodies likely to be commercially important deserve the investment of $\$ 2,000$-plus. 